set off from Khabarova with a Russian, a few Samoyedes and reindeer sledges over the frozen tundra via the Pechora River to Archangel. From there he went on round the White Sea and across the Kola peninsula to Kirkenes in Norway. His book, "The Great Frozen Land" (1895), is full of notes on natural history and on Samoyedes' customs and folklore. With the backing of Mr. A. C. Harmsworth (later Lord Northcliffe), Jackson left for Franz Josef Land in 1894 and made his base at Cape Flora. The Franz Josef Archipelago was little known beyond the few discoveries of Payer and Leigh Smith. Jackson remained three years in the north, surveying some of the little-known islands and distinguishing himself as a hunter of polar bears, of which he shot about a hundred. Among his companions were W. S. Bruce and A. B. Armitage, who in later years distinguished themselves in South Polar work. The expedition's chief claim to fame was due to the chance meeting of Jackson with Nansen and Johansen. On their return from their long poleward march they had wintered on the north of the archipelago, and in 1895 were on their way west toward Spitsbergen when near Cape Flora they met Jackson, a few weeks before the Windward was due. Thus they reached Norway in safety.

After serving in the South African War of 18991902, Jackson contemplated a South Polar expedition but his plans came to nothing. He served in the Great War, and in 1919 had charge of Russian prisoners-of-war camps in Germany. Then in 1925 he turned to Central Africa for adventure and big game shooting, crossing Africa from east to west, visiting the Ruanda country and descending the Congo to the sea. Later he investigated the slave trade of Liberia. In addition to his book on Lapland Jackson wrote "A Thousand Days in the Arctic" (1899) and "The Lure of Unknown Lands" (1935). He was a gold medallist of the Royal Geographical Society, a medallist of the Royal Humane Society and a knight of the Order of St. Olaf.

Jackson's work was essentially of a pioneer order, and it was the opportunity to overcome physical difficulty and danger which drew him to the Arctic and later to Africa. Scientific exploration attracted him less than hunting, but he showed much interest in natural history and, where scope was afforded, in native races and their ways.

R. N. R. B.

\section{Prof. Anton Lampa}

ThE academic career of Prof. Anton Lampa, who died in Vienna on January 28 at the age of seventy years, was under the shadow of the political changes occurring in Austria during his lifetime. Educated in Vienna, he studied physics under von Lang and became Privatdozent and assistant professor in the University of Vienna. In 1909 he was called upon to fill the chair of experimental physics at the German University in Prague; when, in 1918, Czechoslovakia became an independent State, the German University in Prague came under the authority of the new Govermment instead of the
Ministry of Education in Vienna. Although this did not cause any appreciable change of its activities, and almost all of the professors continued their work, Lampa decided to return to Vienna. Since there was no chair available for him there he again became Privatdozent of physics.

This resignation was no doubt facilitated by the variety of Lampa's interests. In experimental physics his name is connected especially with the production of very short electric waves; for several years he held the 'record' with a wave-length of $4 \mathrm{~mm}$. He was much interested in questions of the philosophical foundations of science; here he was a devoted follower of Ernst Mach, and a short biographical sketch which he dedicated to Mach's memory is one of the best introductions into the latter's philosophy. The fact that, already in 1883 , Mach, on general principles, had postulated the relativity of every type of motion (including rotation !) enabled Lampa to be one of the earliest to realize the whole significance of Einstein's theory of relativity. It was largely due to Lampa that the German University of Prague was the first to offer to Einstein a full professorship; he held there the chair of theoretical physics from 1911 until 1912, being in close touch with Lampa.

After his return to Vienna, Lampa devoted much time to educational questions. The various societies for the propagation of knowledge could always count on his support, and for a while he was president of one of them. His memory will be held in honour not only by his professional colleagues but also by many others who shared his literary or philosophical tastes and were aware of the sincerity of this very quiet and unostentatious man. F. A.P.

\section{Mr. A. E. Munby}

By the death of Alan E. Munby on January 19, a great personality has been lost to the world of science and art. Mr. Munby's association with the cause for the advancement and development of science teaching for its intrinsic educational value is well known to many. He was for more than thirty years a member (twice chairman) of the Science Standing Committee of the Royal Institute of British Architects, and no effort did he spare in this capacity in obtaining from scientific and educational bodies all over Great Britain, their views, criticisms, and comments on scientific matters and the manner of their propagation. It is to be regretted that he has not lived to see the full benefits of his labours in this respect.

Mr. Munby was educated at Repton. His early training at Durham, where he was assistant to Prof. Bedson and lectured on chemistry in the adjoining counties, his engagement in research at Cambridge (under Sir Arthur Shipley), and at Heidelberg, and in science teaching at Durham, and Felsted School, well fitted him for that sphere of the profession of architect (which he took up at the age of thirty years) for which he is better known. There is no doubt that while a science master at Felsted opportunities 